\title{
Feasibility Study of Biogas Production and Applications using Rural Biomass in Northern Queensland, Australia.
}

\author{
Ammar Arif Ansari ${ }^{1}$, Ahmed Khalid ${ }^{2 *}$, Cavin Hansel Correia ${ }^{3 *}$, Manush Dheen ${ }^{4 *}$, Ribal Talal ${ }^{5^{*}}$, \\ Yousef Elshamy ${ }^{6^{*}}$ and Florian Doucet ${ }^{7^{*}}$ \\ ${ }^{1}$ School of Engineering and Physical Sciences, Heriot-Watt University, Dubai, UAE
}

\section{Author Emails:}

Ammar Arif Ansari: ammararifansari@outlook.com Ahmed Khalid: ahmed.khalid02@gmail.com Cavin Hansel Correia: cavin.correia@gmail.com Manush Dheen : manushdheen@gmail.com Ribal Talal: rta4@hw.ac.uk Yousef Elshamy: yae3@hw.ac.uk

Florian Doucet: flo.caramel.fd.fd@gmail.com

\subsection{Abstract}

Cape York, in Northern Queensland, Australia, is a remote area with a limited supply of energy, making it very hard for the locals to have an easier life. Locals use diesel as a fuel for transportation which is economically harmful for the environment due to the carbon emissions. The research team found a solution for these problems and decided to design a biogas plant, which will be environmentally friendly, cost effective and will produce job opportunities for the locals. The plant aims to produce biogas from the raw manure of the cattle from the farms in Cairns, a nearby neighborhood. The long-term plan of the plant is to be sustainable and profitable. The business plan predicts the break-even point of the business as 4 months, and payback period as less than a year.

\subsection{Design}

Before deciding the idea of the plant, the team has agreed to one type of fuel that will benefit the people of Cape York. It was decided based on multiple factors such as:

- Sustainability $\{$ Factor 1$\}$

- Adaptability \{ Factor 2\}

- Simplicity $\{$ Factor 3$\}$

- Safety \{ Factor 4\}

- Cost $\{$ Factor 5\}
Keywords: Biofuel, Biogas, Green Energy, Sustainability, Cape York, Energy Plant, Feasibility Study, Economics.
Table 1 shows the table of decision matrix that compares the chosen idea from the initial ideas suggested by the team. The team compared the ideas in many different solutions to the problems provided, the ideas are rated from 15 based on how good the idea is. 5 is very good, and 1 is the least wanted. The biogas idea took the team's interest as it got a total $17 / 25$ score, which is the highest among the other solutions, prior to team decided to go ahead with the biogas idea.

\begin{tabular}{ccccccc}
\hline Factors & 1 & 2 & 3 & 4 & 5 & Total \\
\hline Biogas & $\mathbf{4}$ & $\mathbf{3}$ & $\mathbf{4}$ & $\mathbf{3}$ & $\mathbf{3}$ & $\mathbf{1 7}$ \\
Plant based fuel & $\mathbf{1}$ & $\mathbf{1}$ & $\mathbf{3}$ & $\mathbf{3}$ & $\mathbf{4}$ & $\mathbf{1 2}$ \\
Hydrogen Fuel & $\mathbf{3}$ & $\mathbf{2}$ & $\mathbf{0}$ & $\mathbf{3}$ & $\mathbf{1}$ & $\mathbf{9}$ \\
\hline
\end{tabular}

Table 1: Decision Matrix

- Plant Based Fuel:

Plant based fuel requires agricultural produce which is broken down by enzymes into which is processed with additives. With Cape York having such a low number of plant species, the plant is rendered unsustainable. Adapting and overcoming the issue at hand would require a purchase of plant materials from external suppliers which would consequently increase cost and complicate production measures. While the safety factor for all the propositions remains same due to corresponding fire hazards the plant-based fuel come out on top as the most exorbitant option. 


\section{- Biogas}

Biogas is produced by animal life excretion but the most amount of biogas is produced through cow dung. The potential for biogas production is linked to the retention period and $\mathrm{pH}$ of the analyzed animal manures. Cow dung was one of the top producers of biogas, while sheep manure was average, and pig manure was the least productive. In Cape York the number of cows is 3.2 million, so the number of cow dung is abundant in Cape York as there are a greater number of cattle heads it is less likely the number of biogases decreases. It is one of the easiest ways to produce biogas as it does not require a lot of labor work but in return, it takes about 2 to 3 months to get biogas from cow dung so the amount of cost to run the factory for about 2 to 3 months without any biogas which will cost more for the start of 2 months but after produces biogas it will be used to run the factory and also be provided for the people of Cape York

\section{- Hydrogen fuel}

Hydrogen fuel is made by the chemical electrolysis of water, it is considered a complex, expensive and a dangerous process to design, so the team decided to not go with this idea

\subsection{Overview}

Cape York, although plagued by various issues, suffers from lack of accessibility to regular human necessities, and much more is primarily due to the transportation hindrances. Electricity, although not long ago was not considered an essential need, has increasingly played a dominant role in day-to-day tasks and duties. Running electricity can be costly due to large costs of setting up power grids in such isolated areas. Due to this, majority of the Cape York population relies on diesel generators which on one hand offer a relatively reliable source of electricity but on the other, causes devastating environmental impacts. This is where a biogas plant comes in. The proposed biogas solution revolves around utilizing animal waste and litter undergoing chemical reactions to produce not only the biogas but also useful byproducts such as hydrogen sulfide gas which can be used as fertilizer. Surrounding regions consist of many cattle farmers and as such, produce large amounts of fecal waste. This waste not only harms local ecosystems, pollutes water, but also releases methane which has over 80 times the warming power of carbon dioxide. The biogas plant firstly rids the farmers of the waste management, combines the waste in a digester with slurry consequently refining the produced gas into not only the required fuel but hydrogen sulfide which although may be harmful, can be used as a fertilizer at small scale applications. The refinement process also produces water as a byproduct which can be used for a wide range of applications ranging from sanitation to irrigation. Since the plant is not completely automated, human labor would still be required which translates to multiple job openings for locals whether it is for unskilled or skilled labor. Providing not only a better standard of living for the locals, but the proposal also rids regional farmers of waste and converts it into, vital to them, fertilizer.

\subsection{Design Components and Materials}

\section{- Anaerobic Digester Tank}

Anaerobic digestion is a popular renewable energy source. Methane, carbon dioxide, and hydrogen sulfide are produced throughout the process. This biogas can be used right away in combined heat and power gas engines or converted to biomethane with the same properties as natural gas. The nutrient-dense digestate that results can be utilized as fertilizer.

\section{- Mixer}

Submersible mixers are used in digesters to mix and homogenize the substrate, enhancing the plant's output and avoiding sediments from settling and clogging pipes, which can reduce the plant's efficiency over time. 


\section{- Self-Priming Diesel Pump}

Due to the separation chamber within the pump head, which functions when fluid is retained within the pump head, the design of self-priming pumps affects pump efficiency.

\section{- Reciprocating Pump}

A reciprocating pump is a positivedisplacement pump that collects liquid in an enclosed volume and discharges it under pressure to the desired application, based on the positive displacement of the fluid propelled by a piston or plunger.

\section{- Biogas Filter}

Sodium Hydroxide Solution Filter is another name for these. The biogas will enter from the top of the $\mathrm{NaOH}$ solutionfilled column and be allowed to bubble, removing the produced elemental sulfur and carbon dioxide. Basic and acid chemicals are involved in this process. The strong base is $\mathrm{NaOH}$, and the base is water.

\section{- Biogas Generator}

Food trash, plant materials, cattle manure, and other organic stuff are poured into the tank, but for this project, only cow dung will be used. The matter in the tank is broken down by active bacteria, which produce biogas. This biogas is then piped out of the generator and into your home's main supply in most cases.

\section{- Imhoff Tank}

The Imhoff tank is a primary treatment device for raw slurry that is designed to separate solids from liquids and decompose settled sludge. The sediments are anaerobically digested in the chamber, producing biogas.

\section{- Indoor Pipeline Network}

There's are used in the biogas plant for connecting all the generators and the tanks so that power can be produced

\section{- Solar Panels}

The photovoltaic effect is what makes solar lights work. When a light's photoreceptor detects darkness, it switches on the light, which is usually made up of many light-emitting diodes (LEDs)

\section{- Desulfurizers}

The process of biogas desulfurization can be divided into three stages:

1- The dissolution of $\mathrm{H} 2 \mathrm{~S}$ gas from the gas phase to the liquid phase, according to the theory of two film theories.

2- The intracellular $\mathrm{H} 2 \mathrm{~S}$ is converted and used to remove $\mathrm{H} 2 \mathrm{~S}$ from methane.

\section{- H2S Cylinders}

Hydrogen sulfide is a byproduct of a variety of industrial operations, including oil refining, mining, tanning, wood pulp processing, food processing, craft paper making, and rayon production.

\section{- Biogas Cylinders}

Biogas is a gas formed when organic wastes such as animal dung and plant waste decompose in the absence of oxygen.it is used in energy and for cooking and It's suitable for use in water heating and space (room) heating instruments. 


\subsection{How It Works?}

The first process of the biogas extraction is to get the cow manure or the sludge from the farmers and add it to the anaerobic digesters. the anaerobic digester does its magic without the presence of oxygen, where the microorganisms break down the cow manure by digesting it. After the digestion process methane gas and carbon dioxide is produced and collected from the digester tank. The rest of the sludge will be directly sent to a fertilizer tank to use it as a fertilizer for agriculture

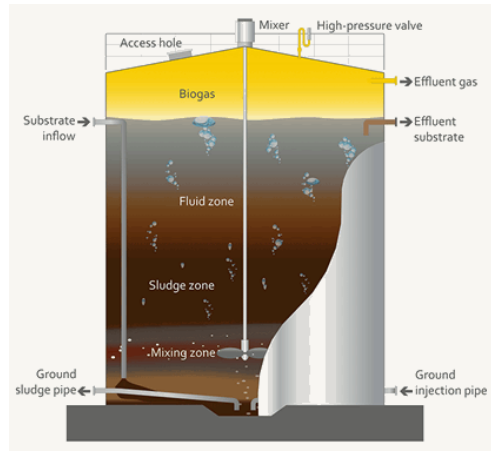

Figure 1: Anaerobic digester purposes. The plant will be having 2 digesters due to the huge mass production, with a capacity of 50 tons per tank. The anaerobic digesters will have a submersible mixer installed to it where it mixes the substances and homogenize it.

The gas extracted from the digester will then be pumped to a biogas filter to separate the biogas from the rest of the impurities. The biogas filter works where water is pumped to the separator and absorbs the co2 gas and separates it from the methane gas.

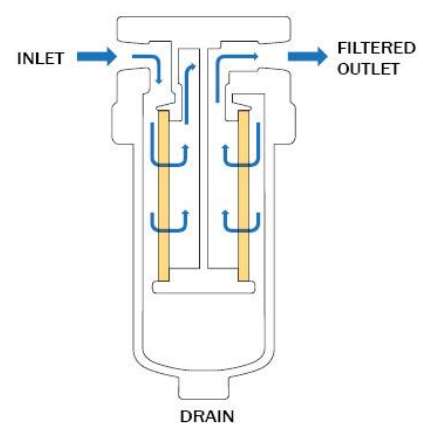

Figure 2: Biogas filter

The biogas filter outlets the water back into the water tank, some small impurities like H2S gas, and the biogas or methane as a product.

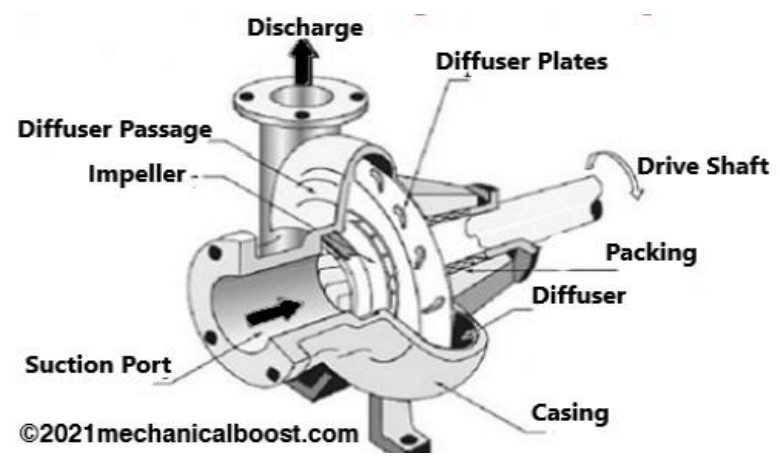

Figure 3: Centrifugal pump

Prior to, The biogas and the $\mathrm{H} 2 \mathrm{~S}$ gas produced will be sent to a storage tank at an equal pressure.

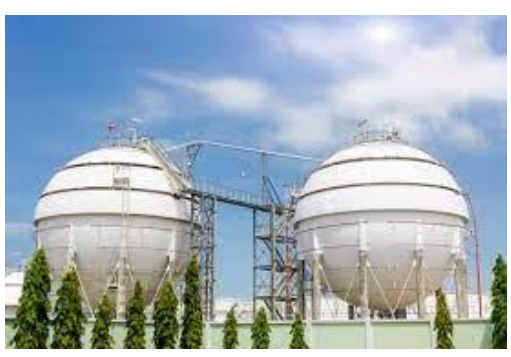

Figure 4: Gas Storage Tanks

The stored biogas and the H2S gas will then be compressed using a compressor pump to be ready for the domestic use for the people of cape York at a highquality biogas. The biogas will be sold in commercial cylinders for cooking purposes, gas fueling pump

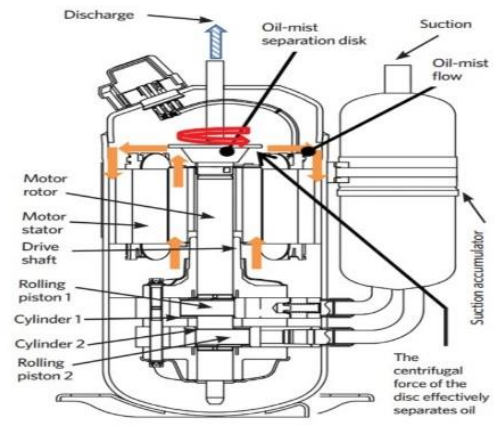
for transport

Figure 5: Compressor Pump purposes or for the biogas generators to help the locals have an easy source of electricity. But the H2S gas will be sold in a commercial cylinder that will then help them with an irrigation system that will help them produce a higher yield of crops 


\subsection{Economics}

Economics encompasses the Investment, Implementation Costs, Maintenance, Human Resource, Customer Acquisition, Taxes, Transportation, Operational Expenses, Miscellaneous costs, Sales Strategies, and Business Plans of the project.

\section{Implementation \& Investment}

\subsection{Short term}

The plant will need a source of funding which will be funded by the government. Once the project is funded, the biogas plant will be in Cairns in Cape York. It is a four-hour drive from Cairns is the town of Rockhampton, which is home to 3.2 million cattle. This makes it an ideal location for manure harvesting to feed the biogas plant. Rockhampton also has good road, rail, sea, and air access which is an advantage for the construction of the biogas plant and the import/export of materials. Once the project is funded in Cairns, the quality of the biogas should be tested before giving it to the locals to determine that the product is at a high-quality fuel, if not the problem must be detected in the plant process and fixed immediately. A year of producing biogas and implemented in the generators and cars to produce electricity for the locals will prove to the community that the biogas fuel plant is beneficial for the community and will not harm or produce any loss. However, some of the locals will be trained in how the plant functions and employed later after getting the hand of it. Most of the training will be on the anaerobic digester, controlling the distillation unit and the mixers and controlling the pumps. This short time period will allow the locals and the government to understand the process and gain a small experience of it, that it would be impossible to gain it in any other way. The locals are encouraged to be honest with their ideas and preferences to help build an improved system that meets the community's needs.
Implementation Costs

\begin{tabular}{|c|c|c|c|}
\hline Item & $\begin{array}{l}\text { CAPEX (per. } \\
\text { Unit) }\end{array}$ & Qty. & Total \\
\hline Anaerobic & AUD & \multirow{2}{*}{2} & AUD \\
\hline Digester Tank & $1,200,000$ & & $2,400,000$ \\
\hline \multirow{2}{*}{ Construction } & AUD & \multirow{2}{*}{1} & AUD \\
\hline & $3,000,000$ & & $3,000,000$ \\
\hline \multirow{2}{*}{$\begin{array}{l}\text { Light } \\
\text { commercial } \\
\text { trucks }\end{array}$} & \multirow[b]{2}{*}{ AUD 25,000 } & \multirow[b]{2}{*}{1} & AUD \\
\hline & & & 25,000 \\
\hline $\begin{array}{l}\text { Service Cost } \\
\text { (Transport) }\end{array}$ & AUD 100 & 1 & AUD 100 \\
\hline \multirow{2}{*}{$\begin{array}{l}\text { Mixer 20hp } \\
15 \mathrm{kwh}\end{array}$} & \multirow{2}{*}{ AUD 75,000 } & \multirow{2}{*}{2} & AUD \\
\hline & & & 150,000 \\
\hline Self-priming & \multirow{3}{*}{ AUD 5,000 } & \multirow{3}{*}{2} & \\
\hline diesel pump & & & AUD \\
\hline 50kwh 72hp & & & \\
\hline \multirow{4}{*}{$\begin{array}{l}\text { Reciprocating } \\
\text { pump } \\
\text { (compressor) } 4 \\
\text { kWh } 18 \mathrm{hp}\end{array}$} & \multirow{4}{*}{ AUD 18,500} & \multirow{4}{*}{2} & \\
\hline & & & AUD \\
\hline & & & 37,000 \\
\hline & & & \\
\hline \multirow{2}{*}{$\begin{array}{l}80-120 \mathrm{~kW} \\
\text { biogas filter }\end{array}$} & \multirow{2}{*}{ AUD 10,000 } & \multirow[t]{2}{*}{2} & AUD \\
\hline & & & 20,000 \\
\hline \multirow{3}{*}{$\begin{array}{c}\text { Biogas } \\
\text { Generator } 75 \\
\text { kWh }\end{array}$} & \multirow{3}{*}{ AUD 13,000 } & \multirow{3}{*}{1} & \\
\hline & & & AUD \\
\hline & & & 15,000 \\
\hline \multirow{2}{*}{$120 \mathrm{~m} 3 \mathrm{tank}$} & \multirow{2}{*}{ AUD 175,000} & \multirow[t]{2}{*}{2} & AUD \\
\hline & & & 350,000 \\
\hline \multirow{2}{*}{$\begin{array}{c}\text { Imhoff Tank } \\
\text { (Slurry/Sludge) }\end{array}$} & \multirow{2}{*}{ AUD 50,000 } & \multirow[t]{2}{*}{$?$} & AUD \\
\hline & & & 100,000 \\
\hline \multirow{2}{*}{$\begin{array}{l}\text { Indoor Pipeline } \\
\text { Network }\end{array}$} & \multirow{2}{*}{ AUD 90,000 } & \multirow[t]{2}{*}{1} & AUD \\
\hline & & & 90,000 \\
\hline \multirow{2}{*}{ Solar panels } & \multirow{2}{*}{ AUD 13,000 } & 1 & AUD \\
\hline & & 1 & 13,000 \\
\hline TOTAL COST & AUI & 208 & \\
\hline & Table 2: Imple & $a t$ & sts \\
\hline
\end{tabular}

\subsection{Long term}

The long-term implementation exists to the effect of the system three years after the introduction of the system. Considering that the plant will work perfectly and meet the standards and ethics of the people in Cape York. The excess biogas fuel will be sold to the rest of Australia as a clean environmentally friendly source of energy, which will also cause a profit to both parties. Also, as a profit of this implementation, the system would be used to research and implement in other remote cities in Australia to help the locals with different type of biomass and biofuel, depending on the resources and the biomass available in the region. It would be also a successful plant design as it meets the standards and ethics of the locals and produces 
green energy for the region. The team also plans to use a purification unit that separates the biogas from the sulfur gas $(\mathrm{H} 2 \mathrm{~S})$ that can help in the irrigation of producing a higher yield of plants, another source of profit apart from the research will be made and the biogas being produced. The $(\mathrm{H} 2 \mathrm{~S})$ can be either sold to other parts of Australia for the farmers or be used by the people of cape York to help them produce better yield in their farm products.

\subsection{Construction Costs}

The price of construction will fluctuate depending on time of year, construction materials, and even different construction companies can offer different deals to finish the construction. On average, the plant will cost around $\$ 3 \mathrm{~m}$ to $\$ 4 \mathrm{~m}$ AUD to construct. This price might be over-estimated since cape York does not have any infrastructure which would make the construction process a little more inefficient financially.

There are also other hidden costs that cannot be covered in minute detail due to their complicated nature. This includes building permits, plot of land, marketing, copyright branding, and even employee salaries.

The plant implementation costs turn out to be approximately AUD 6.2 million as a one-time investment which can be gained/funded through a Partnership or Project Funding. Solar Energy can be used for lighting, powering electronic pieces of equipment, emergency lights, security cameras/devices, etc. (which will not take more than 7-8 $\mathrm{kWh}$ per day 8-10 $1000 \mathrm{kWh}$ Solar Panels, costing in total $\$ 8000-\$ 12000$ in costs). Since it is very expensive to make the whole plan run on solar energy, it will run on the biogas produced instead.

\subsection{Maintenance}

The maintenance costs of the plant are assumed to be around 10\% of Implementation Cost (per year) capped at approximately AUD 620,000 which will cover maintenance of every equipment or vehicle used during the operation of the plant.

Pumps: the pump performance should be monitored for any performance change over time, if the pump fails to operate the cause of the failure must be known to fix the pump. Pumps should be properly sized, dynamically balanced, operated within the specified specs and lubricated. Pumps should also be regularly checked by personnel. Pumps that fail twice for the same reason should be examined closely for a proper installation and whether they operate out of its specified efficiency points.

Reactors: for reactor maintenance the inlet stock should be addressed correctly otherwise there will be a problem of reducing the reaction efficiency. The digester tanks must be examined regularly, and proper preventative measures should be taken. The filters should be examined and changed correctly for finished goods or inlet goods, improper maintenance will cause a sediment seepage into the product or the inlet. Tears will cause filter failure. Air compressors with any size or model require periodic maintenance. Compressor maintenance must be done according to operation hours and not by Calendar. 


\subsection{Human Resource}

Human resources are the number of salaries that is going to be given to the workers, the amount given in the table below is per month salary.

\begin{tabular}{lll}
\hline \multicolumn{1}{c}{ Factors } & \multicolumn{1}{c}{ Value } & \multicolumn{1}{c}{$\begin{array}{c}\text { Total } \\
\text { Value }\end{array}$} \\
\hline $\begin{array}{l}\text { Convertors to } \\
\text { 75\% of Cape } \\
\text { York }\end{array}$ & $1763 \times 122 \$$ & $215,086 \$$ \\
\hline 10 plant workers & $3,500 \$ \times 10$ & $35,000 \$$ \\
\hline $\begin{array}{l}5 \text { maintenance } \\
\text { workers }\end{array}$ & $3,500 \$ \times 10$ & $35,000 \$$ \\
\hline 5 cleaners & $3,500 \$ \times 5$ & $17,500 \$$ \\
\hline Cleaner manager & $4,000 \$$ & $4,000 \$$ \\
\hline $\begin{array}{l}\text { Maintenance } \\
\text { team manager }\end{array}$ & $4,000 \$$ & $4,000 \$$ \\
\hline Biogas engineer & $5,000 \$$ & $5,000 \$$ \\
\hline $\begin{array}{l}\text { 2 Driver \& 2 } \\
\text { dung collectors }\end{array}$ & $3,500 \$ \times 4$ & $14,000 \$$ \\
\hline \multicolumn{2}{c}{ Total $4:$ Human Resources Table } \\
\hline \multicolumn{2}{l}{$329,586 \$$} \\
\hline
\end{tabular}

\subsection{Transportation}

After the production of the biofuel has concluded, it needs to be transported across the region of cape York to be consumed by the population. There are two main methods for this distribution process:

1- Purchasing light commercial trucks as an asset to the biofuel plant. Light commercial trucks can be purchased and used to distribute the biofuel through direct transaction and communication with the consumers. LCTs consume an average of $12.8 \mathrm{~L} /$ $100 \mathrm{~km}$ at \$1.611 AUD per Liter. Average cost of service for a LCT is around \$100 AUD. A hidden cost in this method is the costs of repairs and maintenance if needed. This method has the possibility of being cheaper than purchasing LCTs as assets due to the fact that the biofuel plant is not liable to any inefficiencies, servicing, maintenance, and labor.
2- However, hiring a 3rd party company for doing the distribution, they can charge per kilometer at rates around $\$ 10$ to $\$ 12$ AUD per $\mathrm{km}$. This method's only disadvantage is that the distributer cannot always guarantee a $100 \%$ success rate of distribution due to random probabilities of truck failure, parallax errors, and even late deliveries and pick-ups or communication with the consumers.

\subsection{Operational Cost}

Operational expenses of the plant are encompassed Human Resource, Maintenance, Taxes, and other Miscellaneous costs. The operational expenses are approximately calculated to be around AUD 769,800 per month.

\section{Financials - 2022}

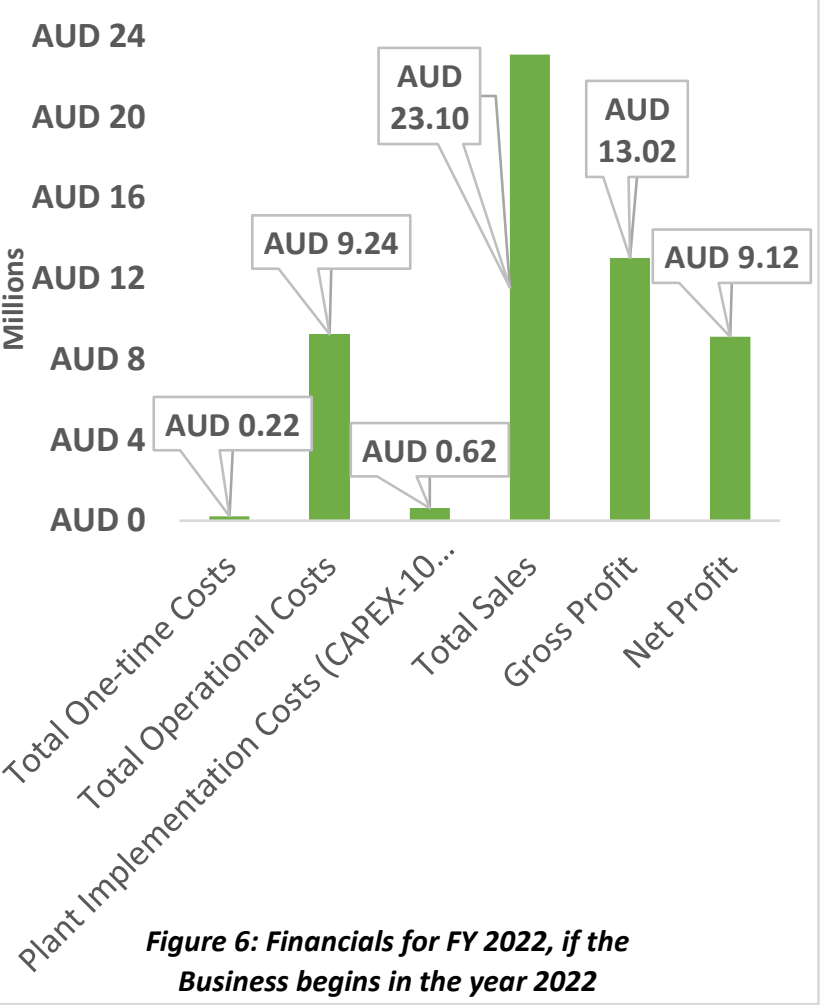




\subsection{Safety and Hazards}

Implementing any design comes with some hazards that the plant workers should be aware of:

\begin{tabular}{|c|c|c|c|}
\hline Hazards & Sources & Results & Measures \\
\hline $\begin{array}{r}\text { Flammable } \\
\text { gas }\end{array}$ & $\begin{array}{l}\text { Biogas is } \\
\text { flammable }\end{array}$ & $\begin{array}{l}\text { Injury or } \\
\text { death }\end{array}$ & $\begin{array}{l}\text { Do not have } \\
\text { anything that } \\
\text { can ignite fire } \\
\text { inside the } \\
\text { plant }\end{array}$ \\
\hline H2s gas & $\begin{array}{l}\text { Inhaling the } \\
\text { gas can } \\
\text { cause } \\
\text { suffocation }\end{array}$ & $\begin{array}{l}\text { Sickness } \\
\text { Loss of } \\
\text { consciousne } \\
\text { ss } \\
\text { Nausea } \\
\text { Death }\end{array}$ & $\begin{array}{l}\text { Make the } \\
\text { plant always } \\
\text { in a ventilated } \\
\text { area }\end{array}$ \\
\hline $\begin{array}{r}\text { High pressure } \\
\text { gas or leaks }\end{array}$ & $\begin{array}{l}\text { High } \\
\text { pressure } \\
\text { biogas can } \\
\text { cause an } \\
\text { explosion } \\
\text { and the leak } \\
\text { may cause } \\
\text { suffocation }\end{array}$ & $\begin{array}{l}\text { Death } \\
\text { Fire } \\
\text { Suffocation }\end{array}$ & $\begin{array}{l}\text { Check for gas } \\
\text { leaks store } \\
\text { biogas in a } \\
\text { sphere } \\
\text { cylindrical }\end{array}$ \\
\hline
\end{tabular}

Table 4: Safety measures to be taken care of

\subsection{Ethics}

The team will ensure that the project will have a full ethical value. The biogas will be produced with a perfect quality. It will be tested by burning in air, if blue fumes appear then the fuel has a high percentage of methane. Also, the calorific value must be calculated, the methane value for biogas should be around $50 \%-75 \%$ and the calorific value should be around $(5000 \mathrm{Kcal} / \mathrm{m} 3)$. The laborers working on the project should be treated well, given the right instructions and be well trained, although the salaries should be paid on time. The rules of cape York will be followed properly, and the environment will be taken care of.

\subsection{Design Analysis}

\subsection{Sustainability}

Our team decided that biodiesel plant will be a perfect idea to help the people in cape York to have a better, more efficient, and to make Cape York a better place. As indicated in the EWB Brief that all human waste collected by trucks which travel all the way from nearby cities is to be treated furthermore. But this human waste can be used in making a clean biodiesel fuel, instead of delivering it to other cities and paying for its transportation cost. Setting up one good-sized Biofuel Plant is a sustainable idea, setting up the plant, a system that will connect all lavatories/toilets, allowing people to dump domestic waste in a dedicated area from where the plant will be induced with all the materials and other very minute ingredients can be used for biofuel generation.

\subsection{Environment}

Studies recommend that biofuels lessen greenhouse gases by as much as sixty five percent. Fossil fuels, while burnt, produce enormous quantities of greenhouse gases i.e., carbon dioxide withinside the atmosphere. These greenhouse gases lure daylight and motivate the planet to warm. Also, biofuel does not produce a lot of carbon emissions which is also an especially important aspect to our environment. Although the manufacturing of biofuels creates carbon dioxide as a byproduct, it is miles often used to develop the vegetation to be transformed into gasoline. This permits it to grow to be something near a self-maintaining system. Besides, biofuels are biodegradable that reduces the opportunity of soil infection and infection of underground water at some stage in transportation, garage, or use. Biofuel is a renewable source of energy, since most ingredients like manure, corn, switchgrass, soybeans, cooking oil waste from plants and vegetation are renewable and will not expire any time soon, it makes the 
usage of biofuels green in nature. Also, those plants may be replanted recursively.

\subsection{Economics}

Calls for much less preservation brings down standard pollutants test costs. Engines running on biofuels produce much less emission than different diesel engines. Also, it will cause economic security as it will increase the call for appropriate biofuel plants, imparting a lift to the agriculture industry. Fueling homes, groups and automobiles with biofuels are much less high-priced than fossil fuels. More jobs can be created with a developing biofuel industry, to preserve the city's financial system secure. According to the RFA (Renewable Fuels Association) February 2019 Ethanol Industry Outlook report, "Ethanol stays the highest-octane, lowest-value motor gasoline at the planet." Additionally, in 2019, U.S. Department of Energy (DOE) allocated seventy-three million dollars for 35 bioenergy studies and development (R\&D) projects. With dreams including decreasing drop-in biofuel costs, its objectives to "permit highprice merchandise from biomass or waste assets" and discount withinside the value of manufacturing biopower. So, the usage of biofuels can be much less of a drain at the wallet. Also, since the source of biofuel is cattle waste and the residue of cooking oils, biofuel will be a lot more efficient than using any source of fossil fuels.

\subsection{Social Benefits}

The people of cape York will easily have electricity available, and it will make their lives easier and more entertained, and it will also make more job opportunity for the locals as this plant will need a labor charge.

\subsection{Flow Schematic}

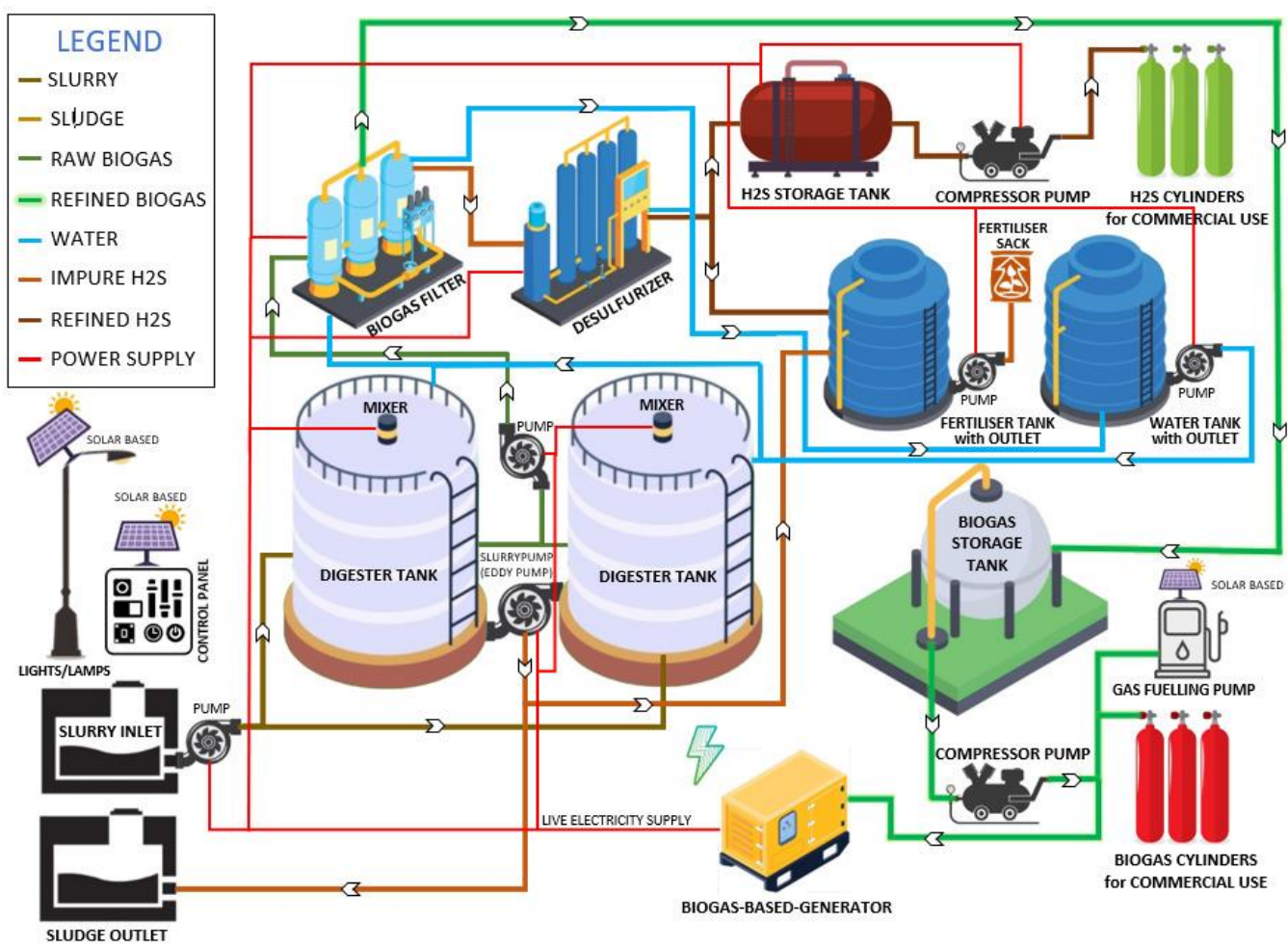

Figure 7: Operation Flow Chart of the Biogas Plant 


\subsection{Plant Location}

Cairns is the town of Rockhampton, which is home to 3.2 million cattle. This makes it an ideal location for manure harvesting to feed the biogas plant. Rockhampton also has good road, rail, sea, and air access which is an advantage for the construction of the biogas plant and the import/export of materials.

\subsection{Swot Analysis}

\section{1- Strengths}

- Producing biogas as a fuel is a more reliable, cheaper, and environmentally friendly source of energy.

- The fuel can also be used to run car engines as it will be cheaper than any source of fuel and produce less carbon emissions.

- The plant will run on biogas fuel as a source of energy, so the plant will produce clean energy and will run on clean energy.

2- Weakness

- Training for the employees needed to work at the plant

- Labor, installation, and maintenance costs will add to the cost

- Most generators in cape York run on diesel so a converter must be bought and added to the local's generators

\section{3- Opportunities}

- The excess biogas produced can be sold outside of cape York to add more profit

- H2S gas produced where it can add to the profit or used in cape York for irrigation to produce more crop yields

- Will produce job opportunities with a fixed salary to the locals

\section{4- Threats}

- Neglecting maintenance will make the plant an extremely dangerous place as an explosion might occur because the biogas produced is flammable

- Not following the safety and risks rules might put the workers at risk

- It will be hard to convince the locals to give away their cow manure

\subsection{Calculations \& Assumptions}

\subsection{Digester Tank \& Storage Tank Calculations}

Average house in Cape York provides living to 4-10 people. A study shows that the amount of waste generated / garbage produced is $\sim 1$ $\mathrm{kg} / \mathrm{day} /$ person.

Along with the cows and herds that produce around $\sim 8 \mathrm{~kg}$ of manures/day which results in production of hundreds of tons of manure per day.

We have manure of,

32000 animals $* 2.5 \mathrm{~kg}=80$ tons

Multiplying it by 42 (as the world standard is to have the size of tank 42 times the input material), our Digester Tank Capacity should be

80 tons $* 42=3360$ tons

32000 animals X $2.5 \mathrm{~kg}$ X 55 liters

$=4400000$ liters of biogas production

Considering cattle manure is supplied by only $1 \%$ of farmers in the region, the plant can produce and meet the requirements of up to 20 days for 20000 households.

Storage Tank Size Required - $4400 \mathrm{~m}^{3}$ (multiple Tanks will be used for the implementation)

\subsection{Production Numbers}

The population of Cape York borders 9000 with an average number of inhabitants per household at 2.8. To provide context for this statistic in terms of power usage, $1 \mathrm{MWh}$ powers up to 1000 households in Texas. Households in Cape York use much less electricity than Texan households; thus, for the purpose of this research, 2000 houses in Cape York will be considered the equivalent of 1000 Texan households, considering only when to power up Cape York. 
To reach this power consumption at an hourly rate, with an average power output of biogas being $1.25 \mathrm{kWh}$ of electricity per liter via a generator. Meaning an average of over 800 liters of biogas will be required at minimum. However, tentatively the number will be increased to 1000 liters as an extreme measure. Therefore, 1000 liters of gas is required per hour. Henceforth, we will need 24000 liters (about the volume of a large U-Haul truck) of Biogas per day.

Since Biogas cannot be produced continuously like a product and is a chemical process, the process needs to be conducted in sessions of 68 weeks, during which, the manure will decompose and disintegrate into Biogas, Fertilizer, and multiple constituents. This makes our plant have 6-7 sessions per year.

As to keep the town moving for 8 weeks without supply, we need a well-managed storage system.

Storage Size Required:

24000 (liters/day) $* 8$ (weeks) $* 7$ (days)

$=\sim 1.4$ million liters

$=\sim 1200 \mathrm{~m}^{\wedge} 3$ Gas Storage Tank

Moreover, storage units for Treasury and Inventory purposes are a necessity; assuming we need inventory for 1 more session (6-8 weeks) which would equal 1.4 million litres, this would eventually need another Gas Tank in the Plant as an Inventory.

The following provides insight into the production rate with respect to cattle excretion:

$1 \mathrm{~kg}$ of Cow Dung Produces $\sim 40$ liters of Biogas

$1 \mathrm{~kg}$ of Chicken Litter $=$ produces $\sim 70$ liters of Biogas
Since there are 3.2 million cattle heads in our selected location, Assuming we convince 1\% of farmers with our excellent strategies to agree on giving their cattle dung, leaving 32000 animals meaning $2.5 \mathrm{~kg}$ of manure per animal at most minimum. Numerically indicating we get an average of 40 liters (via cow dung) +70 liters (via chicken litter), assuming we produce 55 liters of biogas as yield from $1 \mathrm{~kg}$ of manure as a median range.

Therefore,

We have manure in $\mathrm{kgs}$ as,

32000 animals $* 2.5 \mathrm{~kg}=80$ tons

Multiplying it by 42 (as the world standard is to have the size of tank 42 times the input material), our Digester Tank Capacity should be

80 tons $* 42=3360$ tons

32000 animals X $2.5 \mathrm{~kg}$ X 55 liters $=4400000$ liters of biogas production

Considering cattle manure is supplied by only $1 \%$ of farmers in the region, the plant can produce and meet the requirements of up to 20 days for 20000 households.

If successful, this can be scalable enough to become a multi-million-dollar Bioenergy Firm.

Expansive Benefits: If we get $14.6 \%$ of farmers get affiliated to us, we may produce Biogas enough to power all of the Households in Queensland who live out of domestic Generator based electricity (about 17.1\% households in Queensland live on Generators). Operational cost and business plans can be found attached below: 


\subsection{OPERATIONAL COSTS}

\begin{tabular}{|c|c|c|c|c|c|c|}
\hline \multirow{9}{*}{$\begin{array}{l}\text { Manpower } \\
\text { (Salaries) }\end{array}$} & Professionals & Qty. & Salaries (Each) & Total & $\begin{array}{l}\text { Expense } \\
\text { Type }\end{array}$ & $\begin{array}{c}\text { Accumulated } \\
\text { Cost }\end{array}$ \\
\hline & Plant workers & 10 & AUD 3,500.00 & AUD $35,000.00$ & Running & \multirow{8}{*}{$\begin{array}{c}\text { AUD } \\
104,000.00\end{array}$} \\
\hline & Maintenance workers & 5 & AUD 3,500.00 & AUD $17,500.00$ & Running & \\
\hline & Cleaners & 5 & AUD 3,500.00 & AUD $17,500.00$ & Running & \\
\hline & Cleaner manager & 1 & AUD 4,000.00 & AUD 4,000.00 & Running & \\
\hline & Maintenance team manager & 1 & AUD 4,000.00 & AUD 4,000.00 & Running & \\
\hline & Biogas engineer & 1 & AUD 5,000.00 & AUD 5,000.00 & Running & \\
\hline & Truck Driver & 2 & AUD 3,500.00 & AUD 7,000.00 & Running & \\
\hline & Dung collector & 4 & AUD 3,500.00 & AUD $14,000.00$ & Running & \\
\hline \multirow{2}{*}{ Maintenance } & Factor & Investment & Amount & Total & $\begin{array}{l}\text { Expense } \\
\text { Type }\end{array}$ & $\begin{array}{l}\text { Accumulated } \\
\text { Cost }\end{array}$ \\
\hline & $\begin{array}{l}10 \% \text { of Implementation Cost } \\
\text { (Investment) }\end{array}$ & 6208100 & $\begin{array}{c}\text { AUD } \\
620,810.00\end{array}$ & $\begin{array}{c}\text { AUD } \\
620,810.00\end{array}$ & Running & $\begin{array}{c}\text { AUD } \\
620,810.00\end{array}$ \\
\hline \multirow{3}{*}{ Utilities } & Utility & Qty. & Amount & Total & $\begin{array}{l}\text { Expense } \\
\text { Type }\end{array}$ & $\begin{array}{l}\text { Accumulated } \\
\text { Cost }\end{array}$ \\
\hline & Water (Free from Govt.) & $\begin{array}{l}30000 \\
\text { gallons }\end{array}$ & AUD 0.00 & AUD 0.00 & Running & \multirow{2}{*}{ AUD 0.00} \\
\hline & $\begin{array}{c}\text { Electricity (Using Self-Produced } \\
\text { Biogas) }\end{array}$ & 54000 kwh & AUD 0.00 & AUD 0.00 & Running & \\
\hline \multirow{7}{*}{$\begin{array}{c}\text { Transportatio } \\
\mathrm{n}\end{array}$} & Expenses & Qty. & Amount/Unit & Total & $\begin{array}{l}\text { Expense } \\
\text { Type }\end{array}$ & $\begin{array}{l}\text { Accumulated } \\
\text { Cost }\end{array}$ \\
\hline & Driver Salaries & 2 & AUD 3,500.00 & AUD $7,000.00$ & Running & \multirow{6}{*}{$\begin{array}{c}\text { AUD } \\
14,950.00\end{array}$} \\
\hline & Collector Salaries & 2 & AUD 3,500.00 & AUD 7,000.00 & Running & \\
\hline & Engine Converters & 2 & AUD 150.00 & AUD 300.00 & $\begin{array}{l}\text { One- } \\
\text { Time }\end{array}$ & \\
\hline & Telephone Charges & 4 & AUD 35.00 & AUD 150.00 & Running & \\
\hline & $\begin{array}{l}\text { Fuel Expenses (Using Self-Produced } \\
\text { Biogas) }\end{array}$ & - & - & - & $\begin{array}{l}\text { One- } \\
\text { Time }\end{array}$ & \\
\hline & $\begin{array}{l}\text { Collection Equipment } \\
\text { (Spades/Shovels) }\end{array}$ & $10+$ & AUD 50.00 & AUD 500.00 & $\begin{array}{l}\text { One- } \\
\text { Time }\end{array}$ & \\
\hline \multirow{2}{*}{ Raw Materials } & Expenses & Qty. & Amount/Unit & Total & $\begin{array}{l}\text { Expense } \\
\text { Type }\end{array}$ & $\begin{array}{c}\text { Accumulated } \\
\text { Cost }\end{array}$ \\
\hline & Convertors to $75 \%$ of Cape York & 1765 & AUD 122.00 & $\begin{array}{c}\text { AUD } \\
215,330.00\end{array}$ & $\begin{array}{l}\text { One- } \\
\text { Time }\end{array}$ & $\begin{array}{c}\text { AUD } \\
215,330.00\end{array}$ \\
\hline \multirow{6}{*}{$\begin{array}{l}\text { Selling } \\
\text { Expenses }\end{array}$} & Expenses & Qty. & $\begin{array}{c}\text { Amount/Mont } \\
\mathrm{h}\end{array}$ & Total & $\begin{array}{l}\text { Expense } \\
\text { Type }\end{array}$ & $\begin{array}{c}\text { Accumulated } \\
\text { Cost }\end{array}$ \\
\hline & Advertising On News Paper & - & AUD 4,900.00 & AUD 4,900.00 & Running & \multirow{5}{*}{$\begin{array}{c}\text { AUD } \\
27,840.00\end{array}$} \\
\hline & Two Sales Men & 2 & AUD 6,200.00 & AUD 6,200.00 & Running & \\
\hline & Digester Safety Inspection Fee & 1 & AUD 340.00 & AUD 340.00 & Running & \\
\hline & Promotion/Sales & - & AUD 2,500.00 & AUD 2,500.00 & Running & \\
\hline & Newspaper \& Calendars & - & AUD $13,900.00$ & AUD $13,900.00$ & Running & \\
\hline \multirow{2}{*}{$\begin{array}{l}\text { Miscellaneous } \\
\text { Costs }\end{array}$} & Expenses & Qty. & Amount/Unit & Budget & $\begin{array}{l}\text { Expense } \\
\text { Type }\end{array}$ & $\begin{array}{c}\text { Accumulated } \\
\text { Cost }\end{array}$ \\
\hline & Masks/PPE & 30 & AUD 15.00 & AUD 2,500.00 & Running & AUD 5,950.00 \\
\hline
\end{tabular}




\begin{tabular}{|c|c|c|c|c|c|c|}
\hline & Employee Uniform & 30 & AUD 100.00 & AUD $2,500.00$ & $\begin{array}{l}\text { One- } \\
\text { Time }\end{array}$ & \\
\hline & $\begin{array}{c}\text { Safety Kits } \\
\text { (Helmet/Gloves/Boots/Glasses) }\end{array}$ & 30 & AUD 60.00 & AUD 300.00 & $\begin{array}{l}\text { One- } \\
\text { Time }\end{array}$ & \\
\hline & $\begin{array}{l}\text { Accidental Equipment } \\
\text { Maintenance }(\mathrm{AC} / \mathrm{IT})\end{array}$ & - & Variable & AUD 200.00 & Running & \\
\hline & $\begin{array}{l}\text { In-Plant Kitchen Costs } \\
\text { (Snacks/Coffee etc.) }\end{array}$ & - & Variable & AUD 200.00 & Running & \\
\hline & Office Supplies & - & Variable & AUD 100.00 & Running & \\
\hline & Interest/Bank Transfer Fees & - & $\begin{array}{c}2 \% \text { per } \\
\text { Transaction }\end{array}$ & - & Running & \\
\hline & Reimbursement Policies & - & Variable & - & Running & \\
\hline & $\begin{array}{c}\text { Fire Safety Kits } \\
\text { (Blankets/Extinguishers) }\end{array}$ & 3 & AUD 50.00 & AUD 150.00 & $\begin{array}{l}\text { One- } \\
\text { Time }\end{array}$ & \\
\hline \multirow{5}{*}{ Taxes } & Tax & Qty. & Amount & Total & $\begin{array}{l}\text { Expense } \\
\text { Type }\end{array}$ & $\begin{array}{c}\text { Accumulated } \\
\text { Cost }\end{array}$ \\
\hline & Land Tax & 1 & $5 \%$ & Variable & $\begin{array}{l}\text { One- } \\
\text { Time }\end{array}$ & \multirow{2}{*}{ Variable } \\
\hline & Federal Tax (on Profits) & 1 & $30 \%$ & Variable & Running & \\
\hline & Total One-time Costs & \multicolumn{5}{|c|}{$\begin{array}{c}A \cup D \\
769,800.00\end{array}$} \\
\hline & Total Operational Costs / Month & \multicolumn{5}{|c|}{$\begin{array}{c}A \cup D \\
219,080.00\end{array}$} \\
\hline
\end{tabular}

One Session = 2 Months

Table 5: Yearly Operational Costs

\subsection{Realistic Business Plan}

The Business plan plans the growth as $10 \%$ of customers purchasing in the first month and eventually grows $5 \%-10 \%$ every month until $6^{\text {th }}$ month and hence grows at a rate of $25 \%$ since the marketing becomes easier when a large chunk of population uses our product. The Business Plan forecasts the Break-Even Point of the business as 4 months, and completes the Payback Period in less than an year.

\begin{tabular}{lr}
\hline \multicolumn{2}{c}{ Financial Statement FY-2022 } \\
\hline COSTS & AUD 219,080 \\
\hline Total One-time Costs & AUD 9,237,600 \\
\hline Total Operational Costs & AUD 620,810 \\
\hline $\begin{array}{l}\text { Plant Implementation Costs (CAPEX-10 } \\
\text { years) }\end{array}$ & \\
\hline Total Costs & AUD 10,077,490 \\
\hline \hline SALES & $4,400,000$ \\
\hline Biogas Produced (Litres Per Session) & AUD 1.25 \\
\hline Selling Price Per Litre (Biogas) & $73 \%$ \\
\hline$\%$ Of Customers Buying & AUD 19,320,756 \\
\hline Total Sales & AUD 9,243,266 \\
\hline \hline Gross Profit & AUD 6,470,286 \\
\hline Federal Tax & $92 \%$ \\
\hline Net Profit & 4 months after operation \\
\hline Return of Investment (ROI \%) & Profitable in
\end{tabular}

Table 6: Forecasted Financial Statement of Year 2022

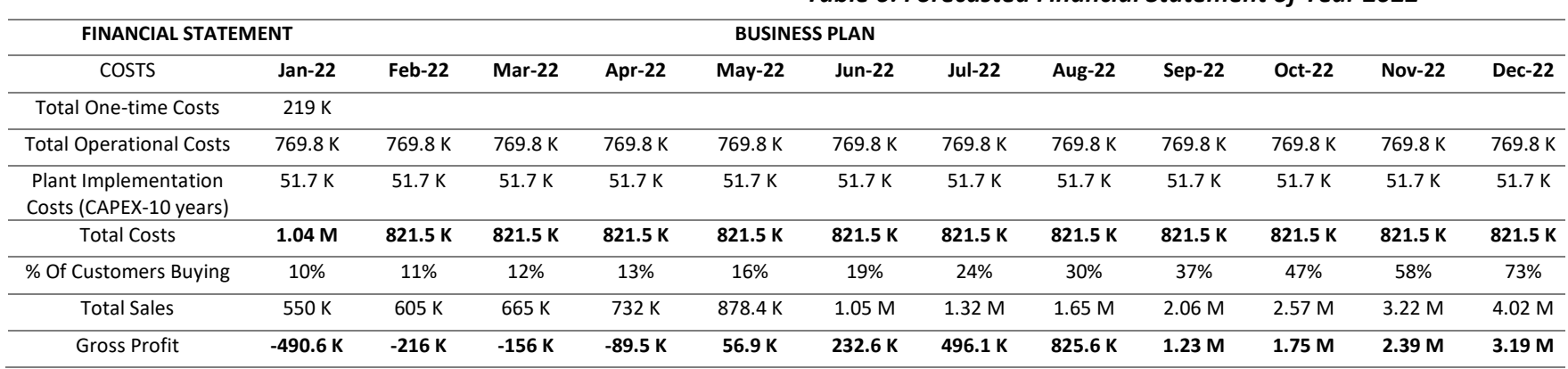

Table 7: Expected Economic results by the end of year 


\subsection{Conclusion}

The aim of the study was to bring light to the dark land of Cape York and providing its inhabitants with green energy. A longterm plan for the implementation of the humanitarian aim was accurately designed undertaking any predicted difficulties. The paper concludes to prove the operation of a Biogas Production plant in Cape York, Northern Queensland, Australia, can be vital for economic and sustainable flourishment of the region. It was proven that Cape York can serve as a great Biogas Production destination worldwide due to availability of abundant resources and ease of access to be utilized in production of Biogas. The case study holds great importance for any energy investor to go further with their business plans, strategies and build a green-energy empire of their own in the region.

\subsection{References}

1. Phelps, M. (2020). Watson River offered with more than 2400 cattle |Video. [online] Queensland Country Life. Available at: https://www.queenslandcountrylife.com.au/st ory/6866431/watson-river-offered-withmore-than-2400-cattle-video/

2. IE, T. (n.d.). 500000L GALVANISED STEEL WATER TANK. [online] Tanks IE. Available at: https://www.tanks.ie/5000001-galvanisedsteel-water-tank/p1983

3. www.advancerockhampton.com.au.

(n.d.). Beef. [online] Available at:

https://www.advancerockhampton.com.au/In dustries/Agribusiness/Beef

4. Encyclopedia Britannica. 2021. Cape York

Peninsula | peninsula, Queensland, Australia. [online] Available at:

<https://www.britannica.com/place/Cape-

York-Peninsula $>$

5. Encyclopedia Britannica. 2021. Torres Strait | strait, Pacific Ocean. [online] Available at: $<$ https://www.britannica.com/place/TorresStrait>
6. Encyclopedia Britannica. 2021. Cairns Queensland, Australia. [online] Available at: <https://www.britannica.com/place/Cairns>

7. Encyclopedia Britannica. 2021. Weipa Queensland, Australia. [online] Available at: $<$ https://www.britannica.com/place/Weipa>

8. Queenslandplaces.com.au. 2021. Cape York Peninsula | Queensland Places. [online] Available at:

$<$ https://queenslandplaces.com.au/cape-yorkpeninsula>

9. World Wildlife Fund. 2021. Cape York Peninsula in northeastern Australia | Ecoregions | WWF. [online] Available at: $<$ https://www.worldwildlife.org/ecoregions/a a0703>

10. Solar Proof Quotes. 2021. 75kW Solar System Information - Facts \& Figures » Solar Proof Quotes. [online] Available at: https://quotes.solarproof.com.au/systemsizes $/ 75 \mathrm{kw}$-solar-system-information-factsfigures/

11. Cape York Report.

Documents.parliament.qld.gov.au. 2021.[online] Available at: https://documents.parliament.qld.gov.au/com mittees/PWC/1997/CapeYork/CapeYorkrpt.pdf

12. Qca.org.au. 2021. Cummings Economics. [online] Available at: https://www.qca.org.au/wpcontent/uploads/2019/05/12144_CummingsEconomics.pdf

13. Quora. 2021. Methane: How much dung can a cow produce in a day? [online] Available at: https://www.quora.com/Methane-Howmuch-dung-can-a-cow-produce-in-a-day

14. Bobbili, s., 2021. Biodiesel Magazine. [Online]

Available at: http://www.biodieselmagazine.com/articles/4 533/plant-maintenance-and-safety

15. groups, T. h., 2021. Horton. [Online] Available at: $\neg$ Solar Proof Quotes. 2021. $75 \mathrm{~kW}$ Solar System Information - Facts \& Figures » Solar Proof Quotes. [online] Available at: $<$ https://quotes.solarproof.com.au/system- 
sizes/75kw-solar-system-information-factsfigures/>

16. Monolith, 2021. Biogas World. [Online] Available at:

https://www.biogasworld.com/news/safetyprecautions-anaerobic-digestion-systems/

17. sources, m. o. n. c. e., 2012. Technology Innovation Management \& Entrepreneurship information service. [Online]

Available at: https://www.technopreneur.net/technology/newtechnologies/energy/biogas.html

18. The Project Definition. 2021. Reciprocating Pump. [online] Available at:

$<$ https://www.theprojectdefinition.com/recip rocating-pump

19. cri-man. 2021. DESIGN OF BIOGAS

PLANT. [online] Available at:

$<$ https://www.cri-man.com/biogas/biogas-

plants $>$

20. Energypedia.info. 2021. Pumps for Biogas Plants - energypedia. [online] Available at: $<$ https://energypedia.info/wiki/Pumps_for_B iogas_Plants>

21. ZUWA-Zumpe GmbH - PUMPS FOR PROFESSIONALS. 2021. Pumps for Biogas Plants | ZUWA-Zumpe GmbH. [online] Available at: $<$ https://www.zuwa.de/en/solutions/pumpsfor-biogas-plants-100/>

22. Generator, W., 2021. What is a Biogas Generator?|Biogas Digester | Cogeneration Experts. [online] Inoplex.com.au. Available at:

https://www.inoplex.com.au/information/wh at-is-a-biogas-generator

23. (2019). How to Conduct a Cost-Benefit Analysis [Online]. Lucidchart Blog. Available at: www.lucidchart.com/blog/costbenefit-analysis

24. [Online]. Available at: www.globalbioenergy.org/uploads/media/03 05_Duncan_-_Cost-of-biodieselproduction.pdf

25. (2021). Biodiesel [Online]. Available at: www.irena.org/costs/Transportation/Biodies el

26. (2021). Cost-Benefit Analysis: Definition and Advantages [Online]. Indeed.com.
Available at: www.indeed.com/careeradvice/career-development/cost-benefitanalysis-advantages.

27. Anaerobic Digesters [Online]. E3A4U: Exploring Energy Efficiency \& Alternatives . Available at: www.e3a4u.info/energytechnologies/anaerobic-digesters/economics/ 